\section{Influenza sim, gripe não}

Influenza, not grippe

Senhor Editor:

Cremos que foi em 1997. Elaboramos matéria, razoavelmente bem divulgada, lamentando a ocorrência de tétano em adultos e idosos, pelo menos conforme verificávamos em nossa atividade no Hospital das Clínicas de São Paulo. Crianças passaram a ser atendidas ali muito raramente, em virtude da boa proteção vacinal referente à doença citada propiciada pelo Programa Nacional de Imunizações.

A moléstia, nas pessoas de grupos etários diversos dos constituídos por jovenzinhos, sobretudo nos velhos é costumeiramente mais grave, pela influência de determinados fatores. Para propiciar adequada e justa assistência tornase necessária estrutura especializada, muito cara, paralelamente à participação permanente de profissionais bem treinados, além de competentes. Esse panorama sem dúvida causa constrangimentos, porquanto é disponível vacina profilática eficientíssima e barata, merecedora de uso amplo no âmbito da saúde pública, por meio de programação bem estipulada.

Por isso, pedimos a adoção de conduta cabível e sensata. Entretanto, nosso intento assumiu dimensão bem maior do que a desejada, pois o Deputado Eduardo Jorge, inspirado em nossas ponderações obteve sucesso ao oficializar campanha nacional de vacinação de idosos, abrangendo também prevenção, por vacinas, da doença pneumocócica e da influenza, ao lado logicamente da desejada profilaxia do tétano. $O$ Deputado Estadual Milton Flavio e o Vereador José Eduardo Martins Cardozo, de São Paulo, elogiavelmente conseguiram êxitos semelhantes em suas áreas de ação.

Em 1999 o resultado alcançado pôde ser tido como satisfatório. A comunidade compreendeu os méritos da programação e aderiu a ela convenientemente. Todavia, em 2000 sucederam percalços como decorrência de algumas circunstâncias e, em especial, frisamos contratempo vinculado à vacinação contra a influenza. O número de vacinados ficou abaixo do almejado. Crendices e boatos afiguraram-se prejudiciais. Por exemplo, vigorou a informação de que governantes pretendiam exterminar velhos por meio de vacina desprimorosa e, outrossim, que esse imunizante causava impotência sexual. Tudo muito insensato e lamentável. Porém, destacamos aspecto que deve ser o mais expressivo nestes comentário: a confusão entre influenza e estados gripais.

Influenza, devida a vírus, é moléstia bem definida, que ao mesmo tempo recebe a designação de gripe, inclusive no âmbito da Medicina. Cada acometimento tem início abrupto e fazem parte dele secreção nasal aquosa associada à sensação de obstrução, febre de elevado porte, dor no corpo com cefaléia assumindo destacadas intensidades e tosse bastante incômoda; persiste durante quatro ou cinco dias em fase de atividade do processo infeccioso e, depois, podem permanecer algumas manifestações arrefecidas, como a tosse por exemplo, acompanhada de expectoração, além de mal-estar, permitindo que vários indivíduos atingidos aleguem demora até advento da cura. Preocupação relevante é a possibilidade de surgirem complicações, ilustradas por broncopneumonia, otite e sinusite, principalmente nos mais suscetíveis.

É imperioso deixar claro que diversas infecções agudas do aparelho respiratório, desencadeadas usualmente por vírus, estreptococo e micoplasma geram sintomatologia em parte semelhante à presente na influenza, ou gripe verdadeira, tornando viáveis confusões, quando na verdade estão vigorando distúrbios singelamente rotuláveis como gripais. Nesse grupo estão: resfriado comum; faringite; laringite; traqueíte; bronquite, pneumonia e pleurite. Lamentavelmente, médicos e leigos diante de tais condições de maneira tranqüila estipulam o diagnóstico de gripe, consumando bagunça conceitual, exigidora de coibição, porquanto corresponde a equívoco, agora cada vez mais pertubadora no campo da saúde pública.

A vacina que previne a influenza é eficiente. Defende $80 \%$ dos vacinados em etapa com um ano de duração, desde que produzida, periodicamente, com inclusão dos vírus prevalentes, pois afigura-se imprescindível contornar as mutações habituais. O imunizante é utilíssimo em diferentes circunstâncias, restritas ou amplas conforme as necessidades; elas vão

Os autores são médicos e professores universitários

Recebido para publicação em 14/6/00. 
desde o emprego para diminuir o absenteísmo, até o planejamento destinado a defender grupos mais vulneráveis, cabendo finalmente a utilização em epidemias.

Parece-nos evidente que a inadequação ressaltada deve ter fim. $O$ apelido de gripe dado à influenza é prejudicial. Para abolir impropriedades, insistamos no privilegiamento de uma única denominação. Assim, haverá correção profissional, ficarão abolidos abusos e projetos preventivos não sofrerão abalos. Acima de tudo, não é justo desmerecer injustamente as virtudes da vacina, nunca defendida como panacéia e valiosa só frente à influenza.

Influenza é influenza. Não é a vulgarizada denominação gripe e muito menos têm vínculo com os abundantes estados gripais.

Vicente Amato Neto e Jacyr Pasternak 